\title{
Investigating the role of gender as a moderator in influencing the intention to use and actual use of mobile telephony
}

\author{
Geeta Kumar ${ }^{1 *}$, Nirupama Prakash²
}

\begin{abstract}
This paper has extended the original Unified Theory of Acceptance and Use of Technology (UTAUT) model through usage space dimensions to investigate the role of Gender in influencing the Intention to use and Actual Usage of Mobile Telephony. A framework based on Usage Space dimensions was developed by reviewing literature and then validating it in the context of Intention to Use and Actual Usage of Mobile telephony. The framework empirically examined the influence of gender as a moderator on the four determinants of the UTAUT model on the Intention to Use and examined for gendered differences in the causality between Intention to Use and Actual Usage among 417 responses. The framework was validated by using Structural Equation Modelling.
\end{abstract}

Among the four determinants considered in the UTAUT model, the influence of gender as a moderator was found in the case of Performance Expectancy (PE), Effort Expectancy (EE) and Facilitating Conditions (FC). Gender as a moderator did not influence the Intention to Use for Social Influence (SI). Gender as a moderator had a very small positive influence, more for men than for women in the case of Actual Usage (AU). The Intention to Use was found to have two distinct use patterns: Inter- Intention to Use (use for world outside) and Intra- Intention to Use (use for self). While the analysis here reinforces

\footnotetext{
${ }^{1}$ Amity International Business School, Amity University, Noida, India

${ }^{2}$ Amity Institute of Social Sciences, Amity University, Noida, India.

*corresponding author; email: geetakumar92@gmail.com
}

earlier studies that point to similarity across genders on the intensity and frequency, there were significant differences in the patterns, motivations and attitudes towards Mobile use that follow conventional gender roles. This Study provides a new research approach towards understanding how users based on gender make use of the multiple features, services and applications in their Mobile phone devices across everyday life dimensions through the Usage space dimensions. A significant new finding of this study revealed that the influence of Intention to Use on Actual Usage is a complex phenomenon and had two distinct use patterns; Inter and Intra Intention to Use.

\section{Keywords}

Mobile Usage Space dimensions, Everyday Life, Intention to Use Mobile Telephony, Actual Usage, Gender.

\section{Introduction}

The Mobile telephony as a technology device has been instrumental in transforming the manner in which individuals and institutions remain socially connected in everyday life. Mobile Phones in its uses and practices have become an accepted part of everyday life. It has penetrated every aspect of daily lives, owned by almost every socio- economic profile in the urban context and become a basic element of work and social life (Campbell, S.W., Ling, R., \& Bayer, 2014; Jacobson, R. P.,Mortensen, C. R., \& Cialdini, 2011; Taipale \& Fortunati, 2014). Mobile Telephony has facilitated the restructuring of daily routines, blurring the lines between public- private, shaping social patterns and habits. The Mobile phone is a good example of a device that dislocates the traditional concept of space and time, enabling its user to bring - not only their network but the world with them. How 
the Mobile Phone and the related technologies is experienced is not totally predetermined by technological functionality or public representations but is structured by social life (Haddon, 2001).

The embeddedness and integration of Mobile Phones in everyday life has been studied in depth by Ling from the individual perspective and from the perspectives of social processes and structures (Ling R, 2004, 2010, 2012). According to Ling, Mobile communication has changed the structure and arrangement of communication at both micro and macro levels. Ling observed that the level of embeddedness of the Mobile is so deep and unconscious that its actual value and need is felt only in the absence of the Mobile device. Mobile Phone in the modern society seems to integrate time, space and communication concepts making it "flexibly instinctive" (Ling R., 2012).

At the individual level, Mobile Phone as a medium of communication has become embedded within the very arrangement of everyday life (Farman, 2012; Ito, M., Okabe, D., \& Anderson, 2010). It has become as important as the wallet, keys and ID's that individuals carry everywhere with them. Mobile telephony use is a complex and contradictory phenomenon; at one end it enables better organization and coordination of everyday life and at the same time it increases the level of complexity of everyday life.

The introduction of any new technology in society and its subsequent access and control is determined by the hierarchies of patriarchy, class and other social variables including gender. The Gendered nature of the Mobile phone is located within and derived from the interactions between various meaning and actual use of the medium. Science and Technology studies (STS) and feminist scholarship approaches focus on the mutual shaping of gender and technology, in which technology is conceptualized as both a source and consequence of gender relations.
Urban professionals as a specific user group are a unique set who by the very nature of work compulsions are required to use their Mobiles extensively. These professionals have to negotiate the contradictory demands of private and professional spheres. To view their intentions towards using Mobiles and their actual usage while negotiating within the public and private spheres using a gendered lens would provide useful insights that engender their reality in their professional and personal lives.

The objective of this study is twofold. To investigate the role of gender in moderating the determinants influencing the Intention to Use Mobile Phone and to investigate the role of gender in influencing causality between Intention to Use and Actual Usage of Mobile Phone in everyday Life.

The study has been arranged into four sections. The first section provides an overview of the literature followed by the section that outlines the proposed research framework. The next section pertains to the research method used in the study. The last section presents an analysis of the results, discussion, conclusions, implications, limitations and future research scope of the study.

\section{Literature Review}

The literature review section has five parts. The first part reviews the literature around Mobile use practices specifically from a gendered perspective. The next part has reviewed studies based on the Unified Theory of Acceptance and Use of Technology (UTAUT), the framework used for this study. This is followed by reviewing everyday life as a concept in Mobile uses and usage space dimensions for expressing Mobile usage and the last part identifies the research gap.

\subsection{Mobile uses from a gendered perspective}

Several studies investigated the gendertechnology relationship for differences in the perception and meaning of technology and its actual uses and also explore to reasons for these 
differences. (Aronsson, G., Dallner, M., \& Aborg, 1994; Busch, 1995) concluded that differences existed in terms of actual usage experience with the technology, the level of training, the ability to exercise autonomy in use and trust. (Faulkner, 2001; Henwood, 1993) highlighted that technology in everyday use and conceptualization was masculine in its orientation. According to (Jin, R., \& Punpanich, 2011), technological devices continue to be representatively and symbolically more associated with men than women. (Borges \& Joia, 2015) in their study of executives in Brazil found that the gendered differences in perception was rooted to structural issues that differentiate women and men based on social roles, work, family, emotional issues etc. Within Gender and Mobile use, (Ganito, 2012) concluded that the mobile phone reinforced the traditional gendering of time and the gendered division of labour. Feminization of Mobile was studied by (Lim, 2014; Shade, 2007) who concluded that the scripts used in the advertising, selling, styling and functionality of the Mobile Phones reinforced traditional gender differences in roles and relations. The gendered scripts emphasize women's primary need and uses of Mobile for social networking, leisure pursuits and maintaining familial communication.

Previous researches have also examined the practical and actual Mobile use patterns, possible reasons for the gender differences (Cardoso, G, Gomes, M. d. C, Espanha, R, \& Araújo, 2007; Geser, 2006; Wang, Xiang, \& Fesenmaier, 2014), cross cultural gendered usage and attitudinal patterns (Baron \& Campbell, 2012), highlighting structural issues ( van Deursen, Bolle, Hegner, 2015), the gender differences in meaning making, role taking and relationships in relation to Mobile Phones (Lim, 2014), gendered identities (Lemish \& Cohen, 2005), Mobile use as a site for power, control and domination (Doron, 2012), gendered difference in perception of Mobile (Forgays, Hyman, \& Schreiber, 2014; Gupta \& Jain, 2015), Mobile as a source of liberation or oppression
(Hjorth \& Lim, 2012) , transnational mothering (Qiu, 2008; Vancea \& Olivera, 2013).

The literature review indicates that structures, social processes, economic cultural, political realities need to be considered in understanding the manifestation of gender differences in Mobile use. Keeping urban professionals as a specific user group of this study, it can be assumed that across both genders, Mobile engagement would be intensive and on the higher side. However, there is need to examine whether intention and actual use of Mobiles are influenced by factors like societal role, work requirements, age, lifestyle, family obligations, and personal needs.

\subsection{The UTAUT model}

The Unified Theory of Acceptance and Use of Technology (UTAUT), is a well-established technology acceptance and use model that was formulated by (Venkatesh et al. 2003). The UTAUT model was developed to explain user intentions to use an information system and subsequent usage behaviour. As compared to the eight previous independent models from which the UTAUT model of Venkatesh et al emerged, UTAUT has been able to explain up to $70 \%$ of the of the variation in usage intention (acceptance) of technology. The UTAUT suggests that the four core constructs that directly determine technology acceptance (behavioural intention) and use (behaviour) are: Performance Expectancy (PE), Effort Expectancy (EE), Social Influence (SI), and Facilitating Conditions (FC) as shown in (Fig 1). In the UTAUT model, PE, EE and $S I$ have direct effects on Behavioural Intention, which along with FC have direct effects on Use Behaviour. In addition to these variables the theory also considers "Moderating Factors which moderate the relations between various constructs and Intention to Use. The Moderators are Gender, Age, Experience, and Voluntariness of use" (Ahmad, 2014). The UTAUT model is presented as (Fig. 1).

This model has been extensively cited, empirically tested, validated, replicated, used 
and modified since its original version across technologies, industries, cultures, countries. In Institutional and organizational context, UTAUT has been tested in Educational institutions e.g. (Birch, A., \& Irvine, 2009), Government organizations e.g. (Zhan, Y., Wang, P., \& Xia, 2011), in Health care e.g. (Ifinedo, 2012; Venkatesh, V., Sykes, T. A., \& Zhang, 2011), within Business organizations e.g. (Anderson, J. E., \& Schwager, 2004), in Digital libraries e.g. (Singh, Sharma, \& Singh, 2015). (Williams et al, 2015), in their exhaustive review of 174 literature on UTAUT based researches from 2004 onwards, found that Mobile technology was the most widely examined technology within communication systems.

It is important to note here, that the original UTAUT study was based on examining the user acceptance of "new" technologies that were introduced and was used to investigate the user's initial perception, and, perception after gaining familiarity with the technology after a period of time. The UTAUT model established the influence of the four constructs of Performance Expectancy, Effort Expectancy, Social Influence, and Facilitating Condition in determining the Intention to Use (IE) and Actual Usage $(A U)$ and also established that Intention to Use (IE) predicts the Actual Usage (AU). No study so far has examined or established the relationship of Facilitating Conditions on the Behaviour Intention. This study premises that organizational, environmental, and technical infrastructure that comprises Facilitating Conditions is likely to influence the Intention to use and proposes to examine this dimension also.

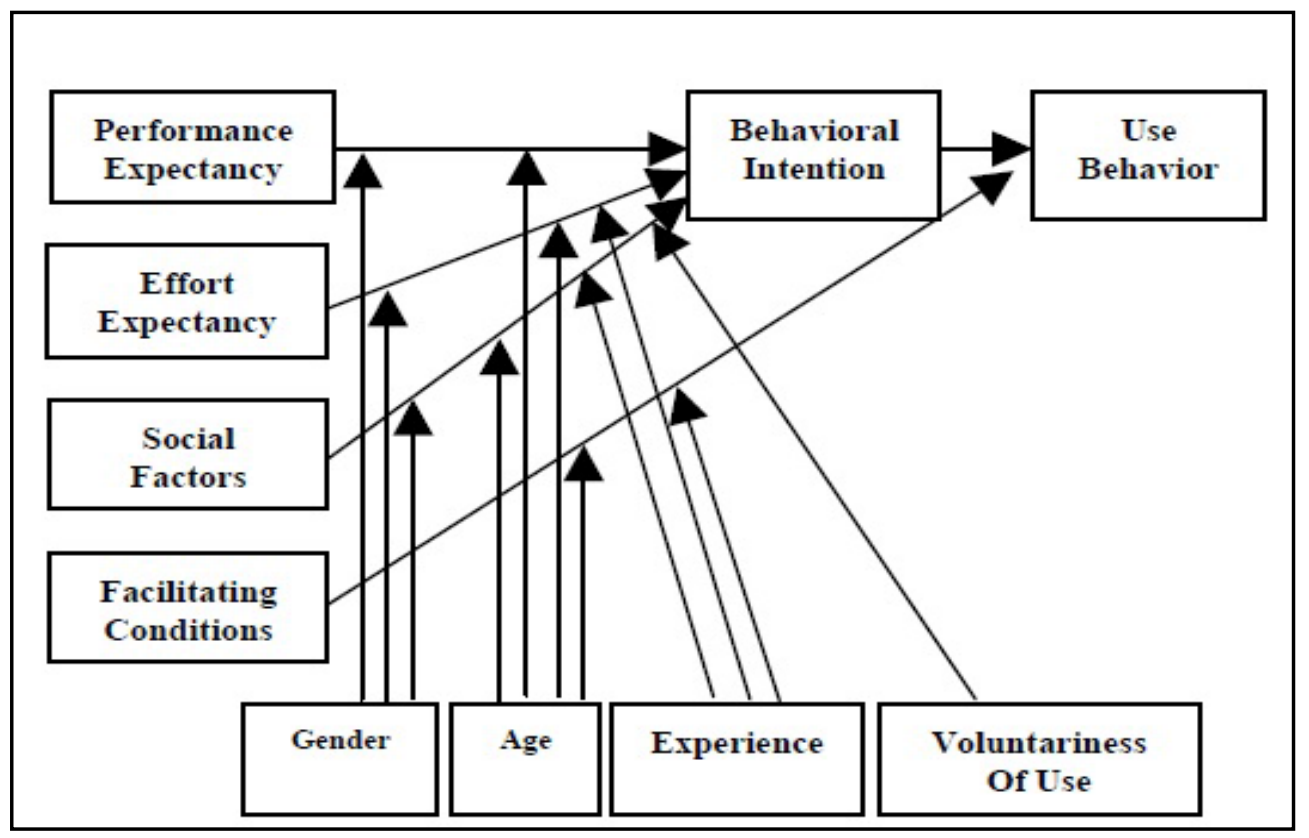

Fig 1 UTAUT Model Source: Venkatesh et al. 2003

With respect to moderating variables, while studies by (Carmen C. Lewis, Cherie E. Fretwell, 2013; Jaradat \& Faqih, 2014; Yi Shun Wang, Ming Cheng Wu, 2009) have considered gender as a moderating variable in the adoption of technologies, studies by (Guo, 2015; Yi Shun
Wang, Ming Cheng Wu, 2009) specifically examined gender as the moderating variable in Mobile use. Apart from these, there is very limited research that has been done to investigate how gender moderates the 
determinants influencing the Intention to Use of Mobiles among users.

Lastly, the original UTAUT study ( Venkatesh et al. 2003) used only three items to measure the Intention to Use ("I intend to use the technology in the next $<\mathrm{n}>$ months, I predict that I would use the technology in the next $<\mathrm{n}>$ month and I plan to use the technology in the next $<n>$ months). The Actual use was measured either with only one item or with system logs. This indicates that until now, the UTAUT model has looked at Intention to Use as a simple variable. Mobile use is an integral part of everyday life now and not a newly adopted technology and has become a one stop technology device to meet most everyday technology needs of individuals such as relationships, work, leisure, information sourcing, financial transactions etc. Therefore, the Intention to Use Mobile is complex and needs a deeper investigation especially for the types and variety of usage. The UTAUT model if used as is, to investigate the Mobile Phone adoption and uses would not be very helpful in understanding which features, applications and services are being used by users as they are contextual and constantly evolving.

\subsection{Everyday Life}

Everyday life " is a modern phenomenon and its impact on human existence and perception (repetitive and uniform aspects of everyday) is associated with industrialization, urbanization and the capitalistic economy"(Lefebvre, 1984). Gender has been an important factor in the conception of everyday life. Woman and their everyday life have commonalities to the nature of everyday (mundane, invisible, insignificant, undervalued and yet indispensable) (Featherstone, 1992). Time, Space and Modality determine everyday life (Felski, 1999). Every day is one of the most omnipresent and nonnegotiable taken for granted lived reality in the human living process. Everyday life encompasses the public and private sphere, including domestic activities besides routine form of work, leisure, travel, and socializing. Every day is actually a way of experiencing the world within the act of performing a set of routine activities within the world. Tasks that appear awkward, strange, difficult initially become second nature gradually like driving or in the current context navigating technology in everyday life. The pragmatic need for repetition, familiarity and taken for grantedness in everyday life is a necessary pre- condition to human survival. (Dén-Nagy, 2014) has observed that the stringent demarcation between the time for work, family, leisure as part of everyday routines are getting diffused with technology intervention.

The Mobile Phone as a device has had a very big role and made a deep impact on the way people have become accustomed to remain socially connected in everyday life. Mobile Phones in its uses, practices have become a natural part of everyday life. It has penetrated every aspect of daily life, owned by almost every socio-economic profiles in the urban context and become a fundamental constituent of social life (Campbell, S.W., Ling, R., \& Bayer, 2014; Jacobson, R. P.,Mortensen, C. R., \& Cialdini, 2011; Taipale \& Fortunati, 2014). (Bayer, Campbell, \& Ling, 2016) developed a model to depict how societal norms and psychological perspectives influence the manner in which connection habits get triggered in everyday Mobile use. (Harmon \& Mazmanian, 2013) identified that Mobile use at once triggers two contradictory discourses; of completely integrating technologically, becoming proficient in multi-tasking or becoming completely disintegrated from Mobile use in everyday life as it distracts and leads to addiction. However, the reality seems somewhere in between.

(Campbell \& Park, 2008) concluded that the personal nature of technology as symbolized by Mobiles is contributing to a completely new type of social arrangement which needs to be understood along with examining the social consequences arising with the large-scale adoption and use of Mobile technologies. (Wajcman, Bittman, Johnstone, Brown, \& Jones, 2008) found that Mobile use has spread across income and occupation levels; varied based on 
age; convenience and micro-coordination was mentioned as the most important reason for use; connecting with family through texting was the most frequent use; managers, traders \& production workers were found to be using the Mobiles most; majority of respondents followed mobile etiquettes like turning their mobile on silent in public settings; safety and indispensability was the typical association with the Mobile . (Barkhuus \& Polichar, 2011) found users to have very individual ways of using their devices that involved complex interplay of adoption, rejection, adjustment, prioritization, creative options for adapting the features and functions in order to make it suitable to the specific needs of users in everyday life.

From Mobile infrastructure point of view, (Lord et al., 2015) explored the role of mobile devices in relation to network connectivity and online services in everyday lives. Everyday life thus, is an important and valuable context for studying Mobile intention to use and usage. There are no comprehensive studies that have examined everyday life use of Mobile Phones as multifunctional and convergent multimedia devices from an urban professional's perspective.

\subsection{Usage Spaces}

The purpose for using Mobiles Phones were identified by (Ling, R., \& Yttri, 1999) as "Safety \& Security, Micro coordination and Hyper coordination" . The Intention to Use Mobile has been summarized as "Mobility, Immediacy and Instrumentality along with sociability and affection " by (Han Sze Tjong, S., Weber, I., \& Sternberg, 2003). Motivational needs of " Personal , Navigation and Social" have been classified by (Tamminen, S., Oulasvirta, A., Toiskallio, K., \& Kankainen, 2004). According to (Katz, J. E., \& Sugiyama, 2005), "power, status and identity" also influence Mobile Phone use. Safety and security as a need for using Mobile Phones has been mentioned by (Campbell, S. \& Russo, 2003; Katz, J. E., \& Sugiyama, 2005; Ling, R., \& Yttri, 1999). All these motivational needs point to Mobile uses being around particular usage spaces such as functionality, safety, relationships navigation, status etc.

Mobile Usage around particular usage spaces has previously been conceptualized by (Marcus, A., \& Chen, 2002a, 2002b, Marcus, 2005a, $2005 \mathrm{~b}$ ) who used the six dimensions of "Identity , Self Enhancement, Relationships, Information, Commerce and Entertainment. These usage space was subsequently tested in the Mobile Phone Technology Usage Model (MOPTUM) by (van Biljon, 2006) who concluded that usage spaces can represent usage variety in a way that is usable and useful to understand actual Mobile use. Usage variety was defined as "the different applications for which, or the different situations in which, a product is used" (van Biljon, 2006).

The review of literature on Mobile usage along usage dimensions suggests that it is easier to express Mobile usage in non- technical terms. Moreover, comparing specific features, services and applications that are technical, continuously evolving and termed differently by different manufacturers is cumbersome. Previous studies validate that usage space dimension is a better, more useful and usable construct to measure Mobile Intention to Use and Actual Usage as compared to the one-dimensional construct used in the original UTAUT. It must however be noted that usage spaces mentioned by previous studies have undergone significant expansion over the last decade and need to be reviewed for additional new usage spaces that will be able to reflect the current contexts.

\subsection{Research Gap}

The Unified Theory of Acceptance and Use of Technology (UTAUT) has mostly examined user acceptance of new technologies. Besides establishing the influence of independent Variables ( $\mathrm{PE}, \mathrm{EE}, \mathrm{SI}, \mathrm{FC})$ and validating a strong positive relationship between Intention to Use and Actual Usage, there are no previous studies that have examined the role of gender as a moderator in influencing Intention of Use on Actual Usage using usage spaces as a measure and using everyday life as a concept. (Michael D 
Williams Nripendra P Rana Yogesh K Dwivedi, 2015) concluded that publications and conferences on UTAUT research have mainly emerged from the US. Thus, there exists opportunities for original research that are region, cultural and context specific. Looking at studies that have specifically considered the moderating effects of gender on Mobile uses, a significant gap in research exists in examining how gender impacts the adoption of mobile usage in the urban Indian context.

\section{Research Framework and Hypotheses}

According to (Williams et al, 2011; Dwivedi et al, 2011), gender as a moderating variable in UTAUT cited articles has not been considered along with all constructs of UTAUT model.

The literature review reveals that the original UTAUT and subsequent studies thereafter have only examined the relationship between Facilitating Conditions and Actual Usage and have overlooked the influence of Facilitating Condition on Intention to use. This study will also examine this relationship.

The research framework (Fig. 2) aims to fill these gaps and explore the moderating role of gender in the domain of Mobile usages among one of the most intensive users of Mobiles, urban professionals.

\section{Objectives}

The study will examine two objectives. The corresponding hypotheses are mentioned alongside the objectives.
1. To investigate the role of gender in moderating the determinants influencing the Intention to Use Mobile Phone.

The following Hypotheses are proposed:

H1: The influence of Facilitating Condition (FC) on the Intention to Use (IE) Mobile Phone will not be moderated by gender.

H2: The influence of Performance Expectancy (PE) on Intention to Use (IE) Mobile Phone will not be moderated by gender.

H3: The influence of Effort Expectancy (EE) on Intention to Use (IE) Mobile Phone will not be moderated by gender.

H4: Social Influence (SI) on Intention to Use (IE) Mobile Phone will not be moderated by gender.

H5: The influence of Facilitating Condition (FC) on the Actual Usage will not be moderated by gender.

2. To investigate the role of gender in influencing causality between Intention to Use and Actual Usage of Mobile Phone in everyday life?

The following hypothesis is proposed:

H6: The Intention to Use (IE) Mobile Phone will not be moderated by gender in influencing its Actual Usage. 


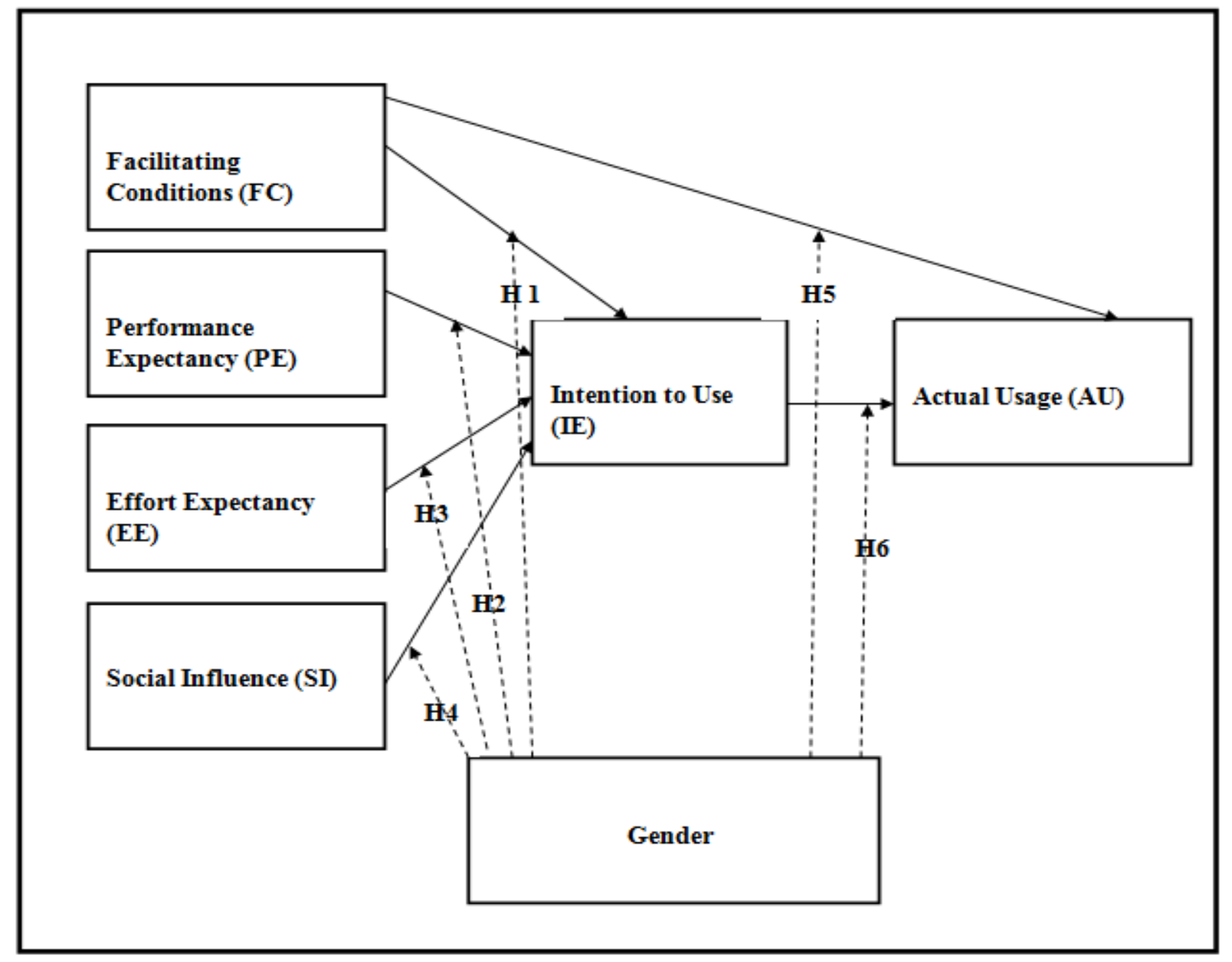

Fig. 2: Research Framework

The working definitions of the Independent Variables, Intention to Use (IE), and Actual Usage (AU) used in this study are provided as (Table 1). This study has examined the Intention to Use (IE) and Actual Usage (AU) from the point of usage space based on the original Usage Space Model conceptualized by (Marcus, A., \& Chen, 2002a, 2002b, Marcus, 2005a, 2005b). Using Marcus and Chen's Usage space model and the MOPTUM model (van Biljon, 2006) as a starting point and based on exploratory interviews, this study identified 12 Usage Spaces that urban professionals usually used in everyday life. Subsequently using Focused Group Discussions, the usage spaces were reduced to 10 as depicted in (Fig. 3).
The Usage Space dimensions along with their definitions have been summarized as (Table 2 ). 


\begin{tabular}{|c|c|c|c|c|}
\hline $\begin{array}{l}\text { S. } \\
\text { No. }\end{array}$ & Variable & Original Definition & $\begin{array}{l}\text { Relevant } \\
\text { References }\end{array}$ & Working Definition \\
\hline 1 & $\begin{array}{l}\text { Facilitating } \\
\text { Conditions } \\
\text { (FC) }\end{array}$ & $\begin{array}{l}\text { The degree to which an } \\
\text { individual believes that } \\
\text { an organizational and } \\
\text { technical infrastructure } \\
\text { exists to support use of } \\
\text { the system. }\end{array}$ & $\begin{array}{l}\text { (Viswanath } \\
\text { Venkatesh, Michael } \\
\text { G. Morris, Gordon } \\
\text { B. Davis, 2003) } \\
\text { pp453 }\end{array}$ & $\begin{array}{l}\text { The degree to which an } \\
\text { urban professional believes } \\
\text { that organizational, } \\
\text { environmental and technical } \\
\text { infrastructure exists to } \\
\text { support the use of Mobile } \\
\text { Phones in everyday life. }\end{array}$ \\
\hline 2 & $\begin{array}{l}\text { Performance } \\
\text { Expectancy } \\
\text { (PE) }\end{array}$ & $\begin{array}{l}\text { The degree to which } \\
\text { the individuals believe } \\
\text { that the use of the } \\
\text { technologies will } \\
\text { results in performance } \\
\text { gains. This may also be } \\
\text { viewed as the } \\
\text { perceived usefulness of } \\
\text { the technologies. }\end{array}$ & $\begin{array}{l}\text { (Viswanath } \\
\text { Venkatesh, Michael } \\
\text { G. Morris, Gordon } \\
\text { B. Davis, 2003) pp } \\
447\end{array}$ & $\begin{array}{l}\text { The degree to which an } \\
\text { urban professional believes } \\
\text { that using a Mobile Phone } \\
\text { would improve his or her } \\
\text { everyday performance. }\end{array}$ \\
\hline 3 & $\begin{array}{l}\text { Effort } \\
\text { Expectancy } \\
\text { (EE) }\end{array}$ & $\begin{array}{l}\text { The degree of ease of } \\
\text { use of the technologies. }\end{array}$ & $\begin{array}{l}\text { (Viswanath } \\
\text { Venkatesh, Michael } \\
\text { G. Morris, Gordon } \\
\text { B. Davis, 2003) pp } \\
450\end{array}$ & $\begin{array}{l}\text { The degree of simplicity } \\
\text { associated with the use of } \\
\text { Mobile Phones in everyday } \\
\text { life. }\end{array}$ \\
\hline 4 & $\begin{array}{l}\text { Social } \\
\text { Influence } \\
\text { (SI) }\end{array}$ & $\begin{array}{l}\text { The extent to which } \\
\text { the individuals believe } \\
\text { that important others } \\
\text { believe that they } \\
\text { should use the } \\
\text { technologies. }\end{array}$ & $\begin{array}{l}\text { (Viswanath } \\
\text { Venkatesh, Michael } \\
\text { G. Morris, Gordon } \\
\text { B. Davis, 2003) pp } \\
451\end{array}$ & $\begin{array}{l}\text { The degree to which an } \\
\text { urban professional } \\
\text { perceives that important } \\
\text { others believe he or she } \\
\text { should use Mobile Phones in } \\
\text { everyday life. }\end{array}$ \\
\hline 5 & $\begin{array}{l}\text { Intention to } \\
\text { Use (IE) }\end{array}$ & $\begin{array}{l}\text { Behaviour intention to } \\
\text { enact the behaviour of } \\
\text { a technology. }\end{array}$ & $\begin{array}{l}\text { (Davis, 1989; } \\
\text { Marcus, A., \& } \\
\text { Chen, 2002; } \\
\text { Viswanath } \\
\text { Venkatesh, Michael } \\
\text { G. Morris, Gordon } \\
\text { B. Davis, 2003) pp } \\
\text { 456 }\end{array}$ & $\begin{array}{l}\text { The degree to which the } \\
\text { urban professional } \\
\text { perceives his or her } \\
\text { motivation in the purpose } \\
\text { and variety of using Mobile } \\
\text { Phones in the various } \\
\text { dimensions of everyday life. }\end{array}$ \\
\hline 6 & $\begin{array}{l}\text { Actual Usage } \\
(A U)\end{array}$ & $\begin{array}{l}\text { The actual use of the } \\
\text { mobile phone } \\
\text { measured in terms of } \\
\text { frequency of use, type } \\
\text { of uses (i.e. how many } \\
\text { different applications), } \\
\text { dimensions of uses in } \\
\text { everyday life. }\end{array}$ & (van Biljon, 2006) & $\begin{array}{l}\text { The degree to which the } \\
\text { urban professional uses } \\
\text { Mobile Phones in the } \\
\text { various dimensions of } \\
\text { everyday life. }\end{array}$ \\
\hline
\end{tabular}

Table 1 Working Definitions 


\begin{tabular}{|l|l|l|}
\hline S. No. & Usage Space Dimensions & Definition \\
\hline 1 & Relationships (REL) & $\begin{array}{l}\text { Building and maintaining relationships e.g. phoning, } \\
\text { messaging friends, family. }\end{array}$ \\
\hline 2 & $\begin{array}{l}\text { Work Management and } \\
\text { Organization (WMO) }\end{array}$ & $\begin{array}{l}\text { Making arrangements, coordinating, scheduling, } \\
\text { communicating for official activities. }\end{array}$ \\
\hline 3 & $\begin{array}{l}\text { Family and Household } \\
\text { Coordination (FHC) }\end{array}$ & $\begin{array}{l}\text { Meal planning, arranging for goods, services, coordinating, } \\
\text { scheduling, supervise children while on the move etc. }\end{array}$ \\
\hline 5 & Expansion (EXP) & $\begin{array}{l}\text { Using Mobiles as a tool for exploring and finding one's way in } \\
\text { new environments, location navigation etc. }\end{array}$ \\
\hline 6 & $\begin{array}{l}\text { Nersonal Information (PI) } \\
\text { on Services and Products } \\
\text { (NPI) }\end{array}$ & $\begin{array}{l}\text { Finding personal information such as Phone books, reminders, } \\
\text { alarm, creating personal history of photos, messages, } \\
\text { recording and storing things, personal health and medical } \\
\text { tracker, spiritual discourses, blogging etc. }\end{array}$ \\
\hline 7 & $\begin{array}{l}\text { Self-Image (SELF) } \\
\text { results, weather, dictionary, reading, stock market etc. }\end{array}$ \\
\hline 8 & $\begin{array}{l}\text { Entertainment and Leisure } \\
\text { (ENT) }\end{array}$ & $\begin{array}{l}\text { Enhancing image by brand, model, ringtone, accessories, } \\
\text { profile picture, other ways of personalizing of the phone. }\end{array}$ \\
\hline 10 & $\begin{array}{l}\text { Listening to music, jokes, playing games, watching videos or } \\
\text { subscribing to chat rooms, reading etc. }\end{array}$ \\
\hline
\end{tabular}

Table 2 Usage Space Dimensions Definitions

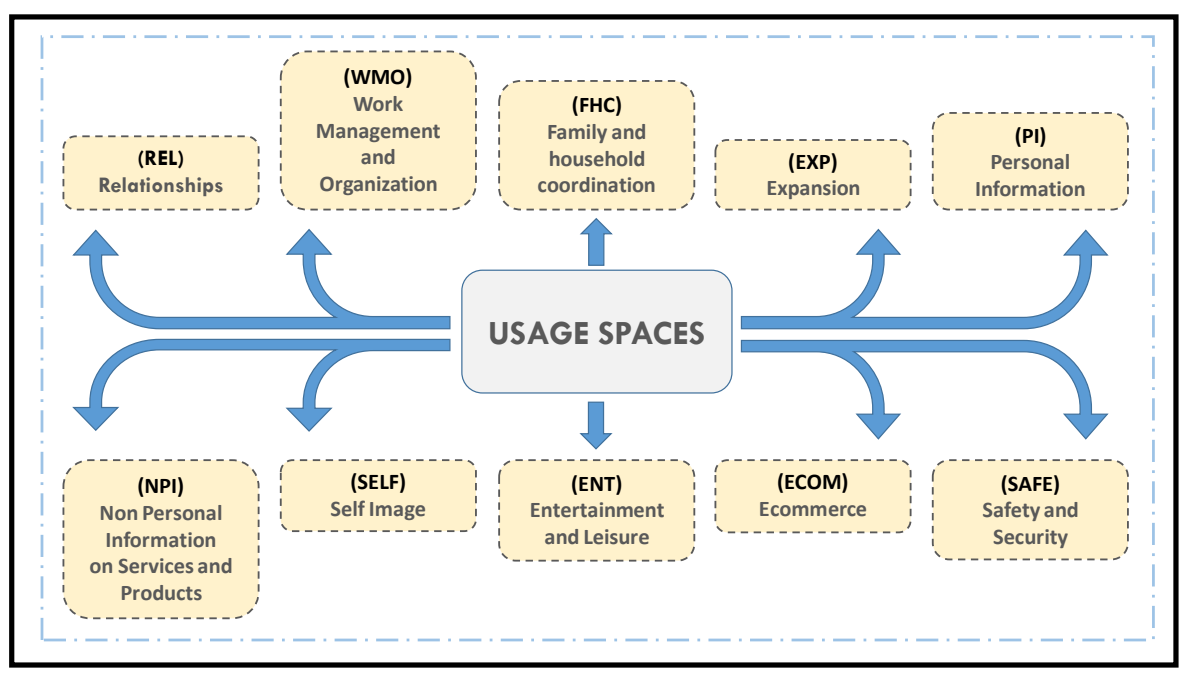

Fig. 3 The Usage Space Dimension 


\section{Research Method}

This section will provide an outline of the research method used in this study.

\subsection{Participants}

The data for this study has been collected from urban professionals located in the National Capital Region (NCR), Delhi. NCR provides a good representation of the Organized sector consisting of Government and Private which includes Indian and Multinational Companies across diverse sectors. The tertiary sector consisting of trade, hotels and restaurants, transport, communications, financial and insurance services, real estate, public administration and other social and personnel services is the key driver of NCR's economy (Economic Survey of Delhi, 2013). It can therefore be concluded that for selecting the Sampling Universe for this research study, NCR has all the criteria required for providing a good representation of the sample of urban professionals.

\subsection{Construct measurement}

The study used standardized statements from the original UTAUT model study with minor modifications for measurement of the Independent Variables (Venkatesh et al. 2003). The Intention to Use and Actual Use were adapted and modified from the MOPTUM model (van Biljon, 2006) and from inputs obtained from exploratory interviews. The pretest for content validity was established with the help of Expert Opinions and Focus Group Discussions for item refinement, addition and deletion. A pilot test was performed on 100 respondents in order to calculate the reliability measure, to assess the consistency of the statements, which showed satisfactory internal reliability and convergent validity. A total of 10 statements for the Independent Variables, 12 statements for Intention to Use and 15 statements for Actual Usage were used to measure the Variables. A five-point Likert scale was used for measuring, 1 being (Strongly Agree) and 5 being (Strongly Disagree).

\subsection{Research Instrument}

A structured questionnaire was used to measure the Intention to Use and Actual Usage behaviour through self-reported usage on a five-point Likert scale, which was different than the original UTAUT model that used log data. The instrument was designed as per the constructs defined previously. The questionnaire contained closedended questions about the various items in each construct. The questionnaire was pre-tested for its structure on a sample of 100 respondents selected through convenience sampling for the purpose of testing the reliability of the questionnaire. Analysis of the pilot study indicated that few of the items within some constructs were not explaining the relation among the constructs. Therefore, necessary modifications were done to establish a more valid relationship among the constructs. A total of 29 statements out of the initial 37 statements altogether were validated and finally used in the model.

\subsection{Data Collection and Sampling}

Data Collection process was undertaken between June and September 2016. The study was proposed on a stratified random sampling which means that groups and categories which are particularly relevant for exploring the research objectives (Gender, Age, Industry Diversity, Managerial Levels in Organizations) were selected to guide the sampling process. Since the study is through a gendered lens, it was essential to bring out comparative data to look at the gendered differences in the Intention to use and Actual Usage of Mobile phones in everyday life of urban professionals. The Structured questionnaire form was administered to a total of 422 professionals in the age group of $21-60$ years. A total of 417 responses were considered valid and have been included in the study out of which 126 (30.21\%) were from women and 291(69.78\%) were from men.

The sample were selected from professionals who belonged to the top 10 occupational group as per the quintile income classes in terms of share of employment in terms of highest Quintile 
income class in Delhi (Institute of Human Development, 2013), were part of the Managerial cadre in the Corporate sector and belonged to the upper most segment of the consuming class-A1, $A 2$ and $B 1$ of the socioeconomic classification, and segments of urban India. These profiles were familiar with electronic gadgets, owned Mobile Phones and were using them in their daily life.

The survey was conducted in three ways; Paper and Pen version, Online version on Google Form and a WhatsApp link also linked to the Google Form. All versions were in English considering the educated profile of the participants. The Paper and Pen version was administered to professionals either in their offices as groups or individually.

\section{Data Analysis and Results}

The data was imported to SPSS 21 and was coded in specific variables. The data were quantitatively analysed and interpreted using SPSS 21 tools. The Confirmatory Factor Analysis (CFA) and Structural Equation Modelling (SEM) were conducted using AMOS 21 software. Establishing the reliability of the different constructs was followed by Exploratory Factor analysis (EFA) after which Confirmatory Factor Analysis (CFA) was performed using structural equation modelling (SEM) to confirm the findings. The following sub-sections describe the result of the analysis.

\subsection{Reliability Analysis}

Cronbach's $\alpha$ was used to evaluate reliability. Values of 0.7 and above are normally considered acceptable (Hair, J. F., Anderson, R. E., Tatham, R. L., \& Black, 1998). Though the Cronbach's coefficient alpha value of .657 for PE and .611 for FC were below the 0.7 threshold, they were not dropped from the model because of their importance in the original model (Table 3). Besides as mentioned by (Field, 2013), values below 0.7 can be expected when working with psychological constructs owing to the diversity of the constructs being measured.

\subsection{Validity Analysis}

Most researchers agree that EFA is usually preferred for developing scales and CFA is more appropriate for validating scales (Hurley et al. 1997). The Independent Variables: PE, EE, SI and FC, are all constructs that have been previously tested in the UTAUT model and therefore construct validity was not required to be verified. Therefore, CFA for establishing the validity of the model was directly performed to check the loadings of the factors, considering that there was an a priori, theoretically-driven specification of factors, i.e., the exact number of factors and how these factors are related to their items (Brown, 2006; Hair et al. 2010).

For Intention to Use (IE) and Actual Usage (AU), factor loadings and KMO and Bartlett's test of sphericity were considered to check validity.

EFA was conducted to check the construct validity. Principal Component Analysis Extraction Method was used and Varimax Rotation Method with Kaiser Normalization converged in 3 iterations for both IE and AU as shown in (Table 4 and 5). It was interesting to observe that in the case of IE, all factors that were concerned with coordinating and using Mobile with the world outside that included Relationship, Work Management \& Organization and Family \&Household Coordination loading under Component 2 These have been termed in this study as Inter Factors. All factors that involved coordinating and using Mobile for personal selfincluded Expansion, Personal Information, NonPersonal Information, Self-Image, Entertainment and Ecommerce loaded on Component1 and have been termed Intra Factors. The value of Kaiser-Meyer-Olkin results (Table 6) were all above 0.8 which is good as anything above 0.7 is acceptable. Barlett's test of sphericity is also significant $(.000)$ as the resultant value is less than .005 (Table 6). Thus, the measures of the scale used in the study show good content validity. Reliability and convergent validity of the factors were estimated by composite reliability and average variance extracted (Table 7). CR of each construct was above or close to 0.7 and AVE of each construct above or close to 0.5, and AVE was less than CR (Bagozzi, RP \& Yi, 1988; Hair et al. 2010), showed good internal consistency . 


\begin{tabular}{|c|c|c|c|}
\hline Factors & Abbreviation & N of Items & Cronbach's Alpha \\
\hline Facilitating Conditions & FC & 3 & .611 \\
\hline Performance Expectancy & PE & 2 & .657 \\
\hline Effort Expectancy & EE & 2 & .750 \\
\hline Social Inclusion & SI & 3 & .730 \\
\hline Intention to Use & IE & 12 & .865 \\
\hline Actual Usage & AU & 15 & .885 \\
\hline
\end{tabular}

Table 3 Reliability Statistics

\begin{tabular}{|c|c|c|}
\hline & \multicolumn{2}{|c|}{ IE } \\
\hline & \multicolumn{2}{|c|}{ Component } \\
\cline { 2 - 3 } & 1 & 2 \\
\hline Relationships (REL) IE & & .797 \\
\hline Work Management and Organization (WMO) IE & & .832 \\
\hline Family and Household Coordination (FHC) IE & & .560 \\
\hline Expansion (EXP) IE & .579 & \\
\hline Personal Information 1 (PI 1)IE & .673 & \\
\hline Personal Information 2 (PI 2) IE & .810 & \\
\hline Personal Information 3 (PI 3) IE & .748 & \\
\hline Non-Personal Information (NPI) IE & .775 & \\
\hline Self-image (SELF) IE & .584 & \\
\hline Entertainment (ENT) IE & .820 & \\
\hline E-commerce (ECOM) IE & .724 & \\
\hline
\end{tabular}

Table 4 Rotated Component Matrix (IE)

Extraction Method: Principal Component Analysis.

Rotation Method: Varimax with Kaiser Normalization (Rotation converged in 3 iterations)

\begin{tabular}{|c|c|c|}
\hline & \multicolumn{2}{|c|}{ AU } \\
\hline & \multicolumn{2}{|c|}{ Component } \\
\cline { 2 - 3 } & 1 & 2 \\
\hline Relationships 1 (REL 1) AU & & 0.769 \\
\hline Relationships (REL 2) AU & & 0.904 \\
\hline Expansion 2 (EXP2) AU & 0.69 & \\
\hline Personal Information 2 (PI2) AU & 0.67 & \\
\hline Non-Personal Information (NPI) AU & 0.736 & \\
\hline E-commerce 1 (ECOM 1) AU & 0.841 & \\
\hline E-commerce 2 (ECOM 2) AU & 0.871 & \\
\hline & & \\
\hline Safety 2 (SAFE2) AU & & 0.719 \\
\hline
\end{tabular}

Table 5 Rotated Component Matrix (AU)

Extraction Method: Principal Component Analysis.

Rotation Method: Varimax with Kaiser Normalization (Rotation converged in 3 iterations) 


\begin{tabular}{|l|l|l|l|}
\hline & & IE & AU \\
\hline Kaiser-Meyer-Olkin Measure & & 0.87 & 0.822 \\
\hline \multirow{3}{*}{ Bartlett's Test of Sphericity } & Approx. Chi-Square & 478.059 & 398.126 \\
\cline { 2 - 4 } & df & 55 & 36 \\
\cline { 2 - 4 } & Sig. & 0 & 0 \\
\hline
\end{tabular}

Table 6 KMO and Bartlett's Test

\begin{tabular}{|c|c|c|c|c|c|}
\hline Construct & Items & \multicolumn{2}{|c|}{ Factor Loading } & CR & AVE \\
\hline \multirow{3}{*}{ FC } & \multirow{3}{*}{3} & $f c 1$ & 0.761 & \multirow{3}{*}{0.7457} & \multirow{3}{*}{0.495474} \\
\hline & & $f c 2$ & 0.643 & & \\
\hline & & fc3 & 0.702 & & \\
\hline \multirow{2}{*}{ PE } & \multirow{2}{*}{2} & pe1 & 0.699 & \multirow{2}{*}{0.61162} & \multirow{2}{*}{0.441253} \\
\hline & & pe2 & 0.627 & & \\
\hline \multirow{2}{*}{$\mathrm{EE}$} & \multirow{2}{*}{2} & ee1 & 0.78 & \multirow{2}{*}{0.800072} & \multirow{2}{*}{0.667197} \\
\hline & & ee2 & 0.852 & & \\
\hline \multirow{3}{*}{$\mathrm{SI}$} & \multirow{3}{*}{3} & si1 & 0.761 & \multirow{3}{*}{0.74654} & \multirow{3}{*}{0.496266} \\
\hline & & si2 & 0.668 & & \\
\hline & & si3 & 0.681 & & \\
\hline \multirow{11}{*}{ IE } & \multirow{11}{*}{11} & REL & 0.797 & & \\
\hline & & WMO & 0.832 & & \\
\hline & & $\mathrm{FHC}$ & 0.560 & & \\
\hline & & EXP & 0.579 & \multirow[b]{2}{*}{0.779054} & \multirow[b]{2}{*}{0.149185} \\
\hline & & PI1 & 0.673 & & \\
\hline & & $\mathrm{PI} 2$ & 0.810 & & \\
\hline & & $\mathrm{PI3}$ & 0.748 & & \\
\hline & & NPI & 0.775 & & \\
\hline & & SELF & 0.584 & & \\
\hline & & ENT & 0.820 & & \\
\hline & & ECOM & 0.724 & & \\
\hline \multirow{8}{*}{$A U$} & \multirow{8}{*}{8} & REL1 & 0.769 & & \\
\hline & & REL2 & 0.904 & & \\
\hline & & SAFE 2 & 0.719 & & \\
\hline & & EXP 2 & 0.690 & \multirow{5}{*}{0.841901} & \multirow[b]{2}{*}{0.240692} \\
\hline & & $\mathrm{PI} 2$ & 0.670 & & \\
\hline & & NPI & 0.736 & & \\
\hline & & ECOM1 & 0.841 & & \\
\hline & & ECOM2 & 0.871 & & \\
\hline
\end{tabular}

Table 7 Internal Consistency 


\subsection{Confirmatory Factor Analysis (CFA)}

A confirmatory factor analysis using AMOS 21 was performed to test the measurement model. Seven common model-fit measures were used to assess the model's overall goodness of fit: the ratio of Chi Square (CMIN) to degrees of freedom $(d f)$, Goodness-of-fit index (GFI), Adjusted Goodness-of-Fit Index (AGFI), Normalised Fit Index (NFI), Comparative Fit Index (CFI), Root Mean Square Residual (RMR) and Root Mean Square Error of Approximation (RMSEA). A model is considered a good fit if the value of the chi-square test is insignificant, and at least one incremental fit index (like CFI, GFI, TLI, AGFI, etc.) and one badness of fit index (like RMR, RMSEA, $S R M R$, etc.) meet the predetermined criteria. Most measures were in the acceptable range which satisfy the criteria for goodness-of-fit as provided in (Table 8).

The comparison of all fit indices with their corresponding acceptable values provides evidence of a good model fit. df, degrees of freedom, goodness-of-fit index; AGFI, adjusted goodness-of-fit index; NFI, normalised fit index; CFI, comparative fit index; RMSR, root mean square residual; RMSEA, The Root Mean Square Error of Approximation.

\subsection{Hypotheses Testing}

Structural Equation Modeling (SEM) was used in order to test the hypotheses pertaining to Intention to Use and Actual Usage. The SEM tested all the six proposed hypotheses in the proposed model at $p<0.05$ significance level. The empirical analysis reveals that alternate Hypotheses $\mathrm{H} 1 \mathrm{a}, \mathrm{H} 2 \mathrm{a}, \mathrm{H} 3 \mathrm{a}$ are accepted. This means that the Influence of Facilitating Conditions (FC), Performance Expectancy (PE) and Effort Expectancy (EE) on Intention to Use (IE) Mobile Phone will be moderated by gender among urban professionals. Null hypothesis $\mathrm{H} 4 \mathrm{O}$ and $\mathrm{H} 5 \mathrm{O}$ are accepted which means that the influence of Social Influence (SI) on Intention to Use (IE) Mobile Phone and the influence of Facilitating Condition on the Actual Usage (AU) will not be moderated by gender among urban professionals. $\mathrm{H} 6 \mathrm{a}$ is accepted which means that that the Intention to Use Mobile Phone among Urban Professionals will be moderated by Gender in influencing its Actual Usage. (Table 9) provides the overall results. (Fig. 4) depicts the Standardized path coefficients for men and women, at significance level, $\mathrm{p}<0.05$.

\section{Discussion and Conclusion}

The Study found that gender as a moderator had an influence in case of FC, PE, EE. This is one of the only studies in the recent past that has examined the relationship between FC- IE. The study revealed that gender as a moderator was stronger for women than for men in case of FCIE. Although, this study has not specifically examined the possible causes for the same, the overall picture suggests that women largely depend on the significant others (usually spouses, children, colleagues) on their Mobile decisions and extending this further, also on the infrastructural support to enable Mobile use. Future studies should investigate this dimension for providing an explanation to this causality. The influence of gender as a moderator in the case of PE was such that it was strong and positive for men and negative for women. This confirms previous researches by (Abdulwahab Lawan, 2012; Carmen C. Lewis, Cherie E. Fretwell, 2013; Chian-Son Yu, 2012; Viswanath Venkatesh, Michael G. Morris, Gordon B. Davis, 2003) that established that PE is stronger for men than for women. In the context of urban professional men, one can hypothesize that they are more task oriented and this reflects in the PE being stronger. The earlier literature reviewed also mentions that gender differences in PE can also be attributed to gender roles and the socialization process which gets reflected even in Mobile use. Gender roles are deeply embedded and more enduring, so any change to occur would be a gradual process. 


\begin{tabular}{|c|c|c|c|c|c|c|}
\hline $\begin{array}{l}\text { Fit } \\
\text { Indicators }\end{array}$ & $\begin{array}{l}\text { Observed } \\
\text { Value } \\
\text { Independent } \\
\text { Variables }\end{array}$ & $\begin{array}{l}\text { Observed } \\
\text { Value } \\
\text { Intention } \\
\text { to Use } \\
\text { (IE) }\end{array}$ & $\begin{array}{l}\text { Observed } \\
\text { Value } \\
\text { Actual } \\
\text { Usage } \\
\text { (AU) }\end{array}$ & $\begin{array}{l}\text { Observed } \\
\text { Value } \\
\text { SEM } \\
\text { Model Fit }\end{array}$ & $\begin{array}{l}\text { Recommended } \\
\text { Value }\end{array}$ & Source \\
\hline CMIN/DF & 3.079 & 3.259 & 3.585 & 2.839 & $\begin{array}{l}1 \leq \mathrm{CMIN} / \mathrm{DF} \leq 3: \\
\text { Very Good } \\
\text { Between 2-5: } \\
\text { Acceptable }\end{array}$ & (Kline, 2004) \\
\hline GFI & .955 & 0.942 & .959 & .937 & $\geq 0.9$ & $\begin{array}{ll}\text { (Joreskog } & \& \\
\text { Sorbom, 2002) } & \end{array}$ \\
\hline AGFI & .914 & 0.911 & .922 & .898 & $\geq 0.8$ & $\begin{array}{ll}\text { (Hu, L.-T., } & \text { \& } \\
\text { Bentler, 1999) } & \end{array}$ \\
\hline NFI & .922 & 0.911 & .765 & .682 & $\geq 0.8$ & $\begin{array}{l}\text { (Bentler, P. M., \& } \\
\text { Bonett, 1980) }\end{array}$ \\
\hline $\mathrm{CFI}$ & .945 & 0.936 & .812 & .755 & $\geq 0.8$ & (Bollen, 1986) \\
\hline RMR & .027 & 0.047 & .065 & .057 & $\leq 0.07$ & $\begin{array}{l}\text { (Browne, M.W. \& } \\
\text { Cudeck, 1993) }\end{array}$ \\
\hline RMSEA & .071 & 0.074 & .079 & .066 & $\begin{array}{l}<0.05 \text { : good fit; } \\
<0.08 \text { : } \\
\text { reasonable fit }\end{array}$ & (Steiger J H, 2007) \\
\hline
\end{tabular}

Table 8: Model Fit Summary

\begin{tabular}{|c|c|c|c|c|c|c|c|c|c|c|}
\hline \multirow[t]{2}{*}{ Relationship } & \multicolumn{3}{|c|}{ Estimate } & \multicolumn{3}{|c|}{$P$ value } & \multicolumn{3}{|l|}{ Results } & \multirow[t]{2}{*}{ Hypotheses } \\
\hline & Overall & w & $\mathbf{M}$ & Overall & $\mathbf{w}$ & M & Overall & W & M & \\
\hline $\begin{array}{l}\mathrm{H} 1 \\
\text { FC-IE }\end{array}$ & 0.53 & 0.57 & 0.48 & $* * *$ & 0.127 & $* * *$ & Sig & NS & Sig & Accept H1a \\
\hline $\begin{array}{l}\mathrm{H} 2 \\
P E-I E\end{array}$ & 0.17 & -0.13 & 0.5 & 0.201 & 0.54 & 0.006 & NS & NS & Sig & $\begin{array}{l}\text { Accept } \\
\mathrm{H} 2 \mathrm{a}\end{array}$ \\
\hline $\begin{array}{l}\mathrm{H} 3 \\
\mathrm{EE}-\mathrm{IE}\end{array}$ & 0.44 & 0.5 & 0.45 & $* * *$ & 0.053 & $* * *$ & Sig & Sig & Sig & Accept H3a \\
\hline $\begin{array}{l}\mathrm{H} 4 \\
\text { SI-IE }\end{array}$ & -0.16 & $\begin{array}{l}- \\
0.294\end{array}$ & $\begin{array}{l}- \\
0.26\end{array}$ & 0.427 & 0.425 & 0.206 & NS & NS & NS & Accept $\mathrm{H} 4 \mathrm{O}$ \\
\hline $\begin{array}{l}\text { H5 } \\
\text { FC-AU }\end{array}$ & 0.09 & 0 & 0.1 & 0.231 & 0.217 & 0.984 & NS & NS & NS & Accept $\mathrm{H} 60$ \\
\hline $\begin{array}{l}\mathrm{H} 6 \\
\mathrm{IE}-\mathrm{AU}\end{array}$ & 0.87 & 0.73 & 0.86 & $* * *$ & $* * *$ & $* * *$ & Sig & Sig & Sig & $\begin{array}{l}\text { Accept } \\
\text { H7a }\end{array}$ \\
\hline
\end{tabular}

* sig, $\mathrm{p}<0.05$

Table 9: Results of Hypotheses Testing 


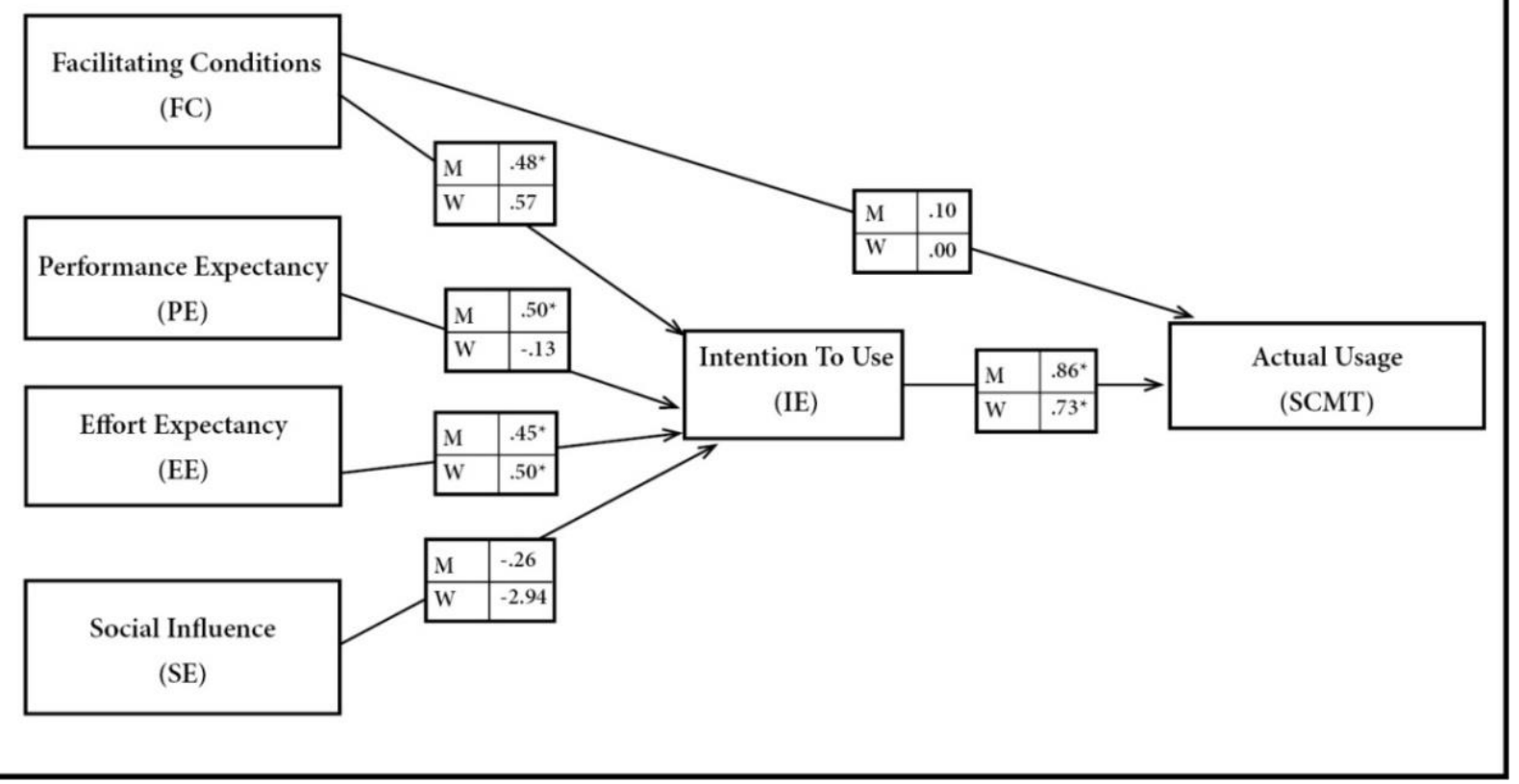

Fig. 4 Standardized path coefficients for Men and Women, * sig, p $<0.05$

In case $\mathrm{EE}$, gender as a moderator was stronger for women than for men which confirms previous researches by (Carmen C. Lewis, Cherie E. Fretwell, 2013; Viswanath Venkatesh, Michael G. Morris, Gordon B. Davis, 2003). However, it is to be noted that with sustained and repetitive usage, the expertise increases which is likely to reduce the influence of EE on IE.

The effect of Social Influence (SI) was insignificant and gender as a moderator did not influence the Intention to use. This finding is contrary to the literature review that indicates that the socialization process and the gendered nature of social roles would influence the $\mathrm{SI}$ on IE such that it would be stronger for women than for men (Abdulwahab Lawan, 2012; Carmen C. Lewis, Cherie E. Fretwell, 2013; Viswanath Venkatesh, Michael G. Morris, Gordon B. Davis, 2003; Yi Shun Wang, Ming Cheng Wu, 2009). Or even otherwise where it was found to be stronger for men than for women (Yi Shun Wang, Ming Cheng $\mathrm{Wu}, 2009)$. This can be explained such that Mobile technology particularly in the context of urban professionals is not a new technology and "with experience the role Social influence is likely to reduce" (Venkatesh et al. 2003, pp 453). The embeddedness and integration of Mobile in everyday life across genders is so deep that life would not function smoothly without the Mobile. Therefore, it can be inferred that Mobile use for urban professionals in mandatory work context or in personal and social context has moved out of the ambit of the influence of important significant others in everyday life.

The path coefficient for FC- AU was also not found to be significant for either men or women. This implies that FC has little role to play in Actual Usage. This can be explained such that urban professionals have found multiple ways to navigate and solicit support for their use in the form of carrying dongles, modems to remove any actual barriers and hindrance such as poor network connectivity to sustained Mobile use.

With respect to gender and the relation between IE- AU, there was high positive, significant causality between Intention to Use (IE) and Actual Usage $(A U)$, being stronger for men than 
for women. This means that the intention to adopt and subsequent use of Mobile Phones also follows the traditional gendered pattern as found in most other technologies where it is initially acquired and adopted by men followed by women. The reason for this gendered pattern has been mentioned in several studies on gender- technology relationship that were discussed previously in the literature review section (Aronsson, G., Dallner, M., \& Aborg, 1994; Borges \& Joia, 2015; Busch, 1995; Faulkner, 2001; Henwood, 1993; Jin, R., \& Punpanich, 2011) .

The study has revealed that the Intention to Use shows two distinct patterns in use when studied from the Usage Space dimensions: Self Usage termed as "Intra Intention to Use" and usage in relation to the world outside termed as "Inter Intention to Use" are important findings of this study that warrant more detailed study across different usage groups. The empirical model used in this study shows that in the case of Intention to Use (IE), the Usage spaces follow a clear distinction between using Mobile for SelfIntra IE (Expansion, Personal Information, NonPersonal Information, Self-Image, Entertainment and Ecommerce) and using Mobile with the World outside- Inter IE (Relationship, Work Management \& Organization and Family \&Household Coordination). This also implies that the influence of Intention to Use on Actual Usage is a complex phenomenon and future studies using UTAUT to study Mobile usage should look at Intention to Use as a multi-dimensional variable.

\section{Implications, limitations and future research scope}

The Practical Implications of this research demonstrates the value of studying reported Intention and Actual usage using a new approach of usage dimensions to analyse adoption on a practical level in the Indian context. It is clear that not everybody uses all the features, applications or services available on the Mobile and therefore the presented approach of studying usages across separate usage dimensions gives a better analysis. For organizations, it provides insights on how differently and similarly Mobiles are being deployed by professionals based on gender. This study has provided an overview on Mobile usage, their negotiation within the public and private spheres which reveal areas for organizations to work on policies to enable professionals to manage their conflicting priorities such as balancing work and family life. From a broader standpoint, the study provides useful insights to further socio- cultural studies of mobile communications through a gendered lens. For Mobile Companies, it provides data that can be utilized for moving the focus from mere functionality of Mobile Features and Services to incorporating the socio- cultural dimensions in designing Mobile Phones and Services.

Although the sample from NCR, Delhi was adequate for the purposes of the present study, future studies could include different and more diverse samples from across India to further enhance variability in responses. Like in all questionnaire-based studies, this study also captured only self-reported usage of the respondents. This can be resolved in future research by undertaking actual observational studies and capturing real time data, using a multi method approach that could make the observations and data more accurate and richer. Another limitation of such a study is the contextual nature of Mobile Uses which are moving targets, are continuously evolving and rapidly changing which makes it difficult to generalize.

With respect to future research directions, future studies using UTAUT to study Mobile usage should look at Intention to Use as a multidimensional variable. This study pointed out the high causality between FC-IE which suggests that future studies must consider FC as an important determinant that influences the Intention to use Mobiles. However, the scope of this study did not include investigating the results between the strong causality of FC-IE and weak FC-AU. It is suggested that future studies 
should examine this dimension for explaining the causality. There is a potential to explore extending the UTAUT model beyond Behaviour Intention and Actual Use Behaviour to also measure consequences and impact in different life spaces of everyday life. The UTAUT model can be quantitatively used to substantiate trends and directions of long-term longitudinal Mobile use consequences and impact.

\section{References}

Abdulwahab, L. 2012, 'A Modification of The Unified Theory of Acceptance and Use of Technology (UTAUT) From Users', Perspectives of Telecentre in Nigeria, Universiti Utara Malaysia.

Ahmad, M.I. 2014, 'Unified theory of acceptance and use of technology', In Fourth International Conference on ICT in our lives, pp.1-4.

Anderson, J. E., \& Schwager, P. H. 2004, 'SME adoption of wireless LAN technology: applying the UTAUT model', In Proceedings of the 7th annual conference of the southern association for information systems, vol. 7, pp.39-43.

Aronsson, G., Dallner, M., \& Aborg, C. 1994, 'Winners and losers from computerization: A study of the psychosocial work conditions and health of Swedish state employees', Journal of Human Computer Interaction, vol. 6, no. 1, pp.17-36.

Bagozzi, RP., \& Yi, Y. 1988, 'On the evaluation of structural equation models', Journal of the Academy of Marketing Science, vol. 16, no. 1, pp.74-94.

Barkhuus, L., \& Polichar, V. E. 2011, 'Empowerment through seamfulness: smart phones in everyday life', Personal and Ubiquitous Computing, vol. 15, no. 6, pp. 629-639.

Baron, N. S., \& Campbell, E. M. 2012, 'Gender and mobile phones in cross-national context', Language Sciences, vol. 34, no. 1, pp.13-27.

Bayer, J. B., Campbell, S. W., \& Ling, R. 2016, 'Connection Cues: Activating the Norms and Habits of Social Connectedness', Communication Theory, vol. 26, no. 2, pp.128-149.

Bentler, P. M., \& Bonett, D. G. 1980, 'Significance tests and goodness-of-fit in the analysis of covariance structures', Psychological Bulletin, vol. 88, pp.588600.

Birch, A., \& Irvine, V. 2009, ' Preservice teachers' acceptance of ICT integration in the classroom: applying the UTAUT model', Educational Media International, vol. 46, no. 4, pp.295-315.

Bollen, K. 1986, 'SAMPLE SIZE AND BENTLER AND
BONETT'S NONNORMED FIT INDEX', The Psychometric Society, vol. 51,no. 3, pp.375-377.

Borges, A. P., \& Joia, L. A. 2015, 'Paradoxes perception and smartphone use by Brazilian executives: Is this genderless', Journal of High Technology Management Research, vol. 26, no. 2, pp.205-218.

Brown, T. 2006, 'Confirmatory factor analysis for applied research. New York: Guilford Press, New York. Browne, M.W., \& Cudeck, R. 1993, 'Alternative ways of assessing model fit. In J. S. Bollen, K.A. \& Long (Ed.), Testing structural equation models', Newbury Park, CA: Sage, pp.136-162.

Busch, T. 1995, 'Gender differences in self-efficacy and attitudes toward computers', Journal of Educational Computing, vol. 12, no. 12, pp. 147-163.

Campbell, S., \& Russo, T. 2003, 'The Social Construction of Mobile Telephony: An Application of the Social Influence Model to Perceptions and Uses of Mobile Phones within Personal Communication Networks', Communication Monographs, vol. 70, no. 4, pp.317-34.

Campbell, S.W., Ling, R., \& Bayer, J. B. 2014, 'The structural transformation of mobile communication. In M. B. O. \& A. Raney (Ed.), Media and social life', New York:Routledge.

Campbell, S. W., \& Park, Y. J. 2008, 'Social Implications of Mobile Telephony: The Rise of Personal Communication Society. Sociology Compass', The Journal Of The British Sociological Association, vol. 2, no. 2, pp.371-387.

Cardoso, G, Gomes, M. d. C, Espanha, R, \& Araújo, V. 2007 Mobile Portugal. Lisbon: Obercom.

Chian-Son, Y. 2012, 'Factors Affecting Individuals to Adopt Mobile Banking: Empirical Evidence from the UTAUT Model', Journal of Electronic Commerce Research, vol. 13, pp.104-121.

Davis, F. D. 1989, 'Perceived Usefulness, Perceived Ease of Use, and User Acceptance of ', MIS Quarterly, vol. 13, no. 3, pp. 319-340.

Dén-Nagy, I. 2014, 'A double-edged sword?: a critical evaluation of the mobile phone in creating work-life balance', New Technology, Work and Employment, vol. 29, no. 2, pp.193-211.

Doron, A. 2012, 'Mobile Persons: Cell phones, Gender and the Self in North India', The Asia Pacific Journal of Anthropology, pp.414-433.

Dwivedi, YK., Rana, NP., Chen, H.M.W. 2011, 'A Metaanalysis of the Unified Theory of Acceptance and Use of Technology (UTAUT)', In IIFIP International Working Conference on Governance and Sustainability in Information Systems-Managing the Transfer and Diffusion of IT, Hamburg, Germany: IFIP InternatioSpringer Berlin Heidelberg, pp.155-170. 
Economic Survey of Delhi, 2013

Farman, J. 2012, 'Mobile interface theory', New York: Routledge.

Faulkner, W. 2001, 'The technology question in feminism: A view from feminist technology studies', Women's Studies International Forum, vol. 24, no. 1, pp.79-95.

Featherstone, M. 1992, 'The Heroic Life and Everyday Life', Theory, Culture and Society, vol. 9, no. 1, pp.165. Felski, R. 1999, 'The Invention of Everyday Life', New Formations: A Journal of Culture, Theory/ Politics, vol. 59, pp.15-31.

Field, A. 2013, Discovering statistics using SPSS (4 ed.), London: Sage, Retrieved from< https://ebooksit.org/1446249174-ebook.htm>

Forgays, D. K., Hyman, I., \& Schreiber, J. 2014, 'Texting everywhere for everything: Gender and age differences in cell phone etiquette and use', Computers in Human Behavior, vol. 31, no. 1, pp.314321.

Ganito, C. 2012, 'Moving Time and Juggling Spheres', Feminist Media Studies, vol. 12, no. 4, pp.570-579.

Geser, H. 2006, 'Are girls (even) more addicted? Some gender patterns of cell phone usage', Sociology in Switzerland: Sociology of the Mobile Phone, pp.1-23. Retrieved from< http://socio.ch/mobile/t_geser3.htm>

Guo, Y. 2015, 'Moderating Effects of Gender in the Acceptance of Mobile SNS Based on UTAUT Model', International Journal of Smart Home, vol. 9, no. 1, pp.203-216.

Gupta, R., \& Jain, K. 2015, 'Adoption behavior of rural India for mobile telephony: A multigroup study', Telecommunications Policy, vol. 39, no. 8, pp.691-704 Haddon. 2001, 'Domestication and mobile telephony. In J. Katz (Ed.), In Machines that become us: The social context of personal communication technology', New Brunswick, NJ: Transaction Publishers, pp.43-56.

Hair, J. F., Anderson, R. E., Tatham, R. L., \& Black, W. C. 1998, 'Multivariate data analysis (5th Edition)', Englewood Cliffs, NJ.: Prentice-Hall.

Hair, JF., Black, WC., Babin, BJ., \& Anderson, R. 2010, 'Multivariate data analysis (7th edn) New Jersey: Prentice Hall', Upper Saddle River, NJ

Han Sze Tjong, S., Weber, I., \& Sternberg, J. 2003, 'Mobile Youth Culture: Shaping telephone use in Australia and Singapore', In ANZCAO3 Conference. Brisbane,

http://www.bgsb.qut.edu.au/conferences/ANZCA03 /Proceedings/papers/Weber_abstract.pdf

Harmon, E., \& Mazmanian, M. 2013, 'Stories of the Smartphone in Everyday Discourse: Conflict, Tension \& Instability', Human Factors in Computing Systems, pp. 1051-1060.

Henwood, F. 1993, 'Establishing gender perspectives in information technology: problems, issues, and opportunities. In D. Green, E., Owen, J. and Pain (Ed.), Gendered by design' Information technology and office systems, London: Taylor and Francis

Hjorth, L., \& Lim, S. S. 2012, 'Mobile intimacy in an age of affective mobile media', Feminist Media Studies, vol. 12, no. 4, pp 477-484.

Hu, L.-T., \& Bentler, P. M. 1999, 'Cutoff criteria for fit indexes in covariance structure analysis: Conventional criteria versus new alternatives', Structural Equation Modeling: A Multidisciplinary Journal, vol. 6, no. 1, pp.1-55.

Hurley, AE., Scandura, TA., Schriesheim, CA., Brannick, MT., Seers, A., Vandenberg, RJ., \& Williams, L. 1997, 'Exploratory and confirmatory factor analysis: Guidelines, issues, and alternatives', Journal of Organizational Behavior, vol. 18, no. 6, pp.667-83.

Ifinedo, P. 2012, 'Technology acceptance by health professionals in Canada: An analysis with a modified UTAUT model In 45th Hawaii International Conference on System Science,(HICSS)', pp. 29372946. IEEE.

Institute of Human Development. 2013, 'Delhi Human Development Report', Retrieved from< www.ihdindia.org/hdidelhi/pdf/chapters/Livelihoods -and-Employment.pdf>

Ito, M., Okabe, D., \& Anderson, K. 2010, 'Portable objects in three global cities: The personalization of urban places. In R. Ling \& S.W. Campbell (Ed.) The reconstruction of space and time:Mobile communication practices', New Brunswick, NJ: Transaction Publishers, pp.67-87.

Jacobson, R. P.,Mortensen, C. R., \& Cialdini, R. B. 2011, 'Bodies obliged and unbound,'Differentiated response tendencies for injunctive and descriptive social norms. Journal of Personality and Social Psychology, vol. 100, no. 3, pp.433-448.

Jaradat, M.-I. R. M., \& Faqih, K. M. S. 2014, 'Investigating the Moderating Effects of Gender and Self-Efficacy in the Context of Mobile Payment Adoption: A Developing Country Perspective', International Journal of Business and Management, vol. 9, no. 11, pp. 147-170.

Jin, R., \& Punpanich, W. 2011, 'Influence of gender difference in reference group on smartphone users' purchasing decision-making process. In Seminar 1st June, 2011, course: BUSM08', degree project in international marketing and brand management, Lund: University-School of Economics and Management.

Joreskog, \& Sorbom. 2002, 'Lisrel VIII: Structural 
Equation Modeling with the SIMPLIS command Language (5th Print). Lincolnwood', IL: Scientific Software International.

Katz, J. E., \& Sugiyama, S. (2005). Mobile phones as fashion statements: The co-creation of mobile communication's public meaning. In R. Ling \& P. Pedersen (Ed.), Mobile communications: Renegotiation of the social sphere (pp. 63-81). Surrey, UK: Springer.

Katz, J. E., \& Sugiyama, S. 2005, 'Mobile phones as fashion statements: The co-creation of mobile communication's public meaning. In R. Ling \& P. Pedersen (Ed.), 'Mobile communications: Renegotiation of the social sphere', pp. 63-81. Surrey, UK: Springer.

Kline, R. B. 2004, 'Beyond Significance Testing: Reforming Data Analysis Methods in Behavioral Research. American Psychological Association.

Lefebve, H. 1984, 'Everyday Life in the Modern World', New York: Transaction Publishers

Lemish, D., and Colen, A.A. 2005, 'On the Gendered Nature of Mobile Phone Culture in Israel', Sex Roles: A Journal of Research, vol. 52, no. 7-8, pp.511-521. Lewis, CC., E. Fretwell, CE, J. R. and J. B. P. 2013, 'Faculty Use of Established and Emerging Technologies in Higher Education: A Unified Theory of Acceptance and Use of Technology Perspective', International Journal of Higher Education, vol. 2, no. 2, pp.22-34.

Lim, S.S. 2014, 'Women, " double work" and mobile media : The more things change, the more they stay the same. In G. Goggin \& L. Hjorth Ed', Routledge Companion to Mobile Media, London: Routledge, pp.356-364.

Ling, R., and Yttri, B. 1999, 'Nobody sits at home and waits for the telephone to ring: Micro and hyper coordination through the use of the mobile phone', Kjeller, Norway, vol. 30.

Ling, R. 2004, 'The Mobile Connection: the Cell Phone's Impact on Society', New York: Morgan Kaufmann

Ling, R. 2010, 'New tech, new ties: How mobile communication is reshaping social cohesion', Cambridge, MA.: The MIT Press

Ling, R. 2012, 'Taken for grantedness!: the embedding of mobile communication into Society', Cambridge, Mass: MIT Press.

Lord, C., Hazas, M., Clear, A.K., Bates, O., Whittam, R., Morley, J., Friday, A. 2015, ' Demand in My Pocket: Mobile Devices and the Data Connectivity Marshalled in Support of Everyday Practice', In Understanding Everyday Use of Mobile Phones- Human Factors in Computing Systems, CHI, Seoul, Korea, pp.2729-
2738.

Marcus, A., \& Chen, E. 2002a 'Designing the PDA of the future'. Interactions, vol. 9, no. 1, pp.34-44.

Marcus, A. 2005, 'Tutorial: Cross-Cultural UserInterface Design for Work, Home, Play and on the way. Paper presented at the In CHI-SA. Johannesburg, South Africa

Marcus, A., \& Chen, E. 2002b, 'Development of a Future Wireless Information Device', In Re: Wireless, Mobile Device Design Seminar, pp.1-7. American Center for Design.

Marcus, A. 2005b, 'Tutorial: Mobile user-interface design for work, home, play and on the way', Paper presented at the In CHI-SA. Cape Town, South Africa, Qiu, J.L. 2008, 'Working class ICTs, migrants and empowerment in South China', Asian Journal of Communication, vol. 18, no. 4, pp. 333-347.

Shade, L.R. 2007, 'Feminizing the Mobile: Gender Scripting of Mobiles in North America', Continuum: Journal of Media \& Cultural Studies, vol. 21, no. 2, pp. 179-189.

Singh, T., Sharma, A., Singh, N. 2015, 'Digital Library Acceptance Model and Its Social Construction: Conceptualization and Development', Journal of Web Librarianship, vol. 9, no. 4, pp.162-181.

Steiger, J.H. 2007, 'Understanding the Limitations of Global Fit Assessment in Structural Equation Modeling', Personality and Individual Differences, vol. 42, no. 5, pp.893-898.

Taipale, S., and Fortunati, L. 2014, 'Capturing methodological trends in mobile communication studies', Information, Communication \& Society, vol. 17, no. 5, pp. 627-642.

Tamminen, S., Oulasvirta, A., Toiskallio, K., Kankainen, A. 2004, 'Understanding mobile contexts', Personal and Ubiquitous Computing, vol. 8, no. 2, pp.135-143. van Biljon, J.A. 2006, 'A model for representing the motivational and cultural factors that influence mobile phone usage variety', Retrieved from < http://uir.unisa.ac.za/bitstream/handle/10500/2149 /thesis.pdf;jsessionid=AD409CD0FBD623BA6916953 7D0B0E850? sequence $=1>$

van Deursen, Alexander J.A.M., Bolle, Colin L., Hegner, Sabrina M., P. A. M. K. 2015, 'Modeling habitual and addictive smartphone behavior: The role of smartphone usage types, emotional intelligence, social stress, self-regulation, age, and gender'. Computers in Human Behavior, vol. 45, pp. 411-42. Vancea, M., and Olivera, N. 2013, 'E-migrant women in Catalonia: Mobile phone use and maintenance of family relationships', Gender, Technology and Development, vol. 17, no. 2, pp.179- 203.

Venkatesh, V., Sykes, T.A., Zhang, X. 2011, 'Just what 
the doctor ordered: A revised UTAUT for EMR system adoption and use by doctors', In, 44th Hawaii International Conference on System Sciences, IEEE, pp.1-10.

Venkatesh, V., Morris, M.G., Gordon, B., Davis, F.D.D. 2003, 'User acceptance of information technology: Toward a unified view', MIS Quarterly, vol. 27, no. 3, pp. 425-478.

Wajcman, J., Bittman, M., Johnstone, L., Brown, J., Jones, P. 2008, 'The Impact of the Mobile Phone on Work / Life Balance', Research School of Social Sciences, Retrieved from <www.amta.org.au > Wang, D., Xiang, Z., Fesenmaier, D.R. 2014, 'Adapting to the mobile world: A model of smartphone use', Annals of Tourism Research, vol. 48, pp.11-26.

Wang, S.Y., Cheng, M., W.H.Y. 2009, 'Investigating the determinants and age and gender differences in the acceptance of mobile learning', British Journal of Educational Technology, vol. 40, no. 1, pp.92-118.

Williams, M.D., Rana, N.P., Dwivedi, Y. K. 2015, 'The unified theory of acceptance and use of technology (UTAUT): a literature review', Journal of Enterprise Information Management, vol. 28.

Williams, M., Rana, N., Dwivedi, Y.B.L. 2011, 'Is UTAUT really used or just cited for the sake of it? A systematic review of citations of UTAUT's originating article', In ECIS Helsinki, Finland, Retrieved from < http://aisel.aisnet.org/ecis2011/231 >

Zhan, Y., Wang, P., Xia, S. 2011, 'Exploring the drivers for ICT adoption in government organization in China'. In Fourth International Conference on', Business Intelligence and Financial Engineering ,BIFE, IEEE, pp.220 -223. 